\title{
CORRESPONDENCE
}

Who's going to win the Olympics?

T Khosla, PHD .............. 40 Priorities in the NHS

A L Cochrane, FRCP; J C Gunn, MD; H

Campbell, FFCM ...............

Glucose is dextrose is glucose

D N Baron, FRCP, and N McIntyre, FRCP . . . 41

Accidents on holiday

M J Merlin, fRCS ..............42

Dangers of tinted glasses for driving

M J Gilkes, FRCs...............42

Management of motor neurone disease

C J Goodwill, MrCP..............42

Multiple sclerosis among immigrants

G Dean, FRCP.............. 42

Folate-responsive neuropathy

E H Reynolds, MD . . . . . . . .

A question of conscience

J M Alston, FRCP; Lillian Versteeg, MB . . . . 443

Management of eclampsia

D R W Hartley, MRCOG

"Practical Medicine"

P R Daggett, MRCP, and D M Geddes, MRCP . . 43

Age of menarche

T C Dann, MD ..............43

Treatment of dermatomyositis

W G Bradley, DM, and J N Walton, FRCP... .43

Routine preoperative chest radiography

G Evison, FRCR ...............
Treatment of metabolic alkalosis

T L Chambers, MRCP.............44

Prostaglandins in depression

Gillian M Craig, MD . . . . . . . . . . . . 44

Erectile impotence

G R Freedman, FRCGP. . . . . . . . . 4

Cervical smears

J Elizabeth Macgregor, MD...........44

Psychological sequelae of therapeutic abortion

J M Kellett, MRCPSYCH.

Effects of legal termination on sul

pregnancy

Ruth E Coles, MB, and Beryl A Tully, MB . . . 45

Flupenthixol for depression

J H Dowson, MRCPSYCH............45

Methysergide ineffective in spasticity

G M Yuill, MRCP...............45

Homoeopathy

C K Elliott, мғном..............45

Oral lesions in tuberculosis

I McO Laws, MB, FDSRCS. .

Genetic counselling in Huntington's chorea

Gillian $M$ Glendinning, $M B$, and $N W$

Glendinning, $\mathrm{MD} \ldots \ldots \ldots \ldots \ldots \ldots 46$

Outpatient laparoscopic sterilisation

Major R H Jago, FFARCS..............46

Prevention of coronary heart disease

revention of coronary heart disease
Once-daily treatment of hypertension

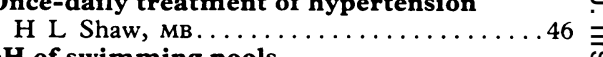

pH of swimming pools

$\mathrm{H}$ Gordon, MFCM.

Thiamine in vegetarian diets

Defects in sphygmomanometers

$\mathrm{S}$ Conceicao, $\mathrm{MD}$, and others...........47

Tattooing for port-wine stains

$S$ Hishon, MRCP..............47 ஸे

New-product pruritus

M J Roberts, мв..............47

Erythema infectiosum (fifth disease)

F Brandrup, $M D$, and P $\varnothing$ Larsen, $M D \ldots \ldots \ldots 47 \vec{\omega}$

Quality of life

R Hudson-Evans, Mrcs............48

Danger of instant adhesives

G T Watts, FRCS...........

Nitrazepam and diazepam

Training of medical laboratory technicia...48 Constance A C Ross, FRCPATH...........48

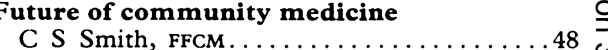

Consultant contract

$\mathrm{J}$ Kyle, FRCS.

Plight of the younger consultant

P C Reed, FRCS; M J Armstrong, MRCOG . . . 49

Hospital practitioner grade

E O Evans, fRCGP................49
Correspondents are urged to write briefly so that readers may be offered as wide a selection of letters as possible. So many are being received that the omission of some is inevitable. Letters should be signed personally by all their authors.

\section{Who's going to win the Olympics?}

SIR,-The USA has dominated the Olympic Games on most of the 18 occasions since their revival in 1896 by winning the largest number of medals. The USSR entered the competitions in a modest way in 1956, seriously challenged the supremacy of the USA in 1968 (USA 107 medals; USSR 91), and replaced the Ameri-

cans as the champions of the games by winning 99 medals to the USA's 93 in 1972. A detailed analysis of the failure of the USA to maintain its leading position at Munich will be reported next year.

The accompanying table lists the categories of events for males in decreasing order of medals

Male Medallists from USA and USSR, Munich 1972

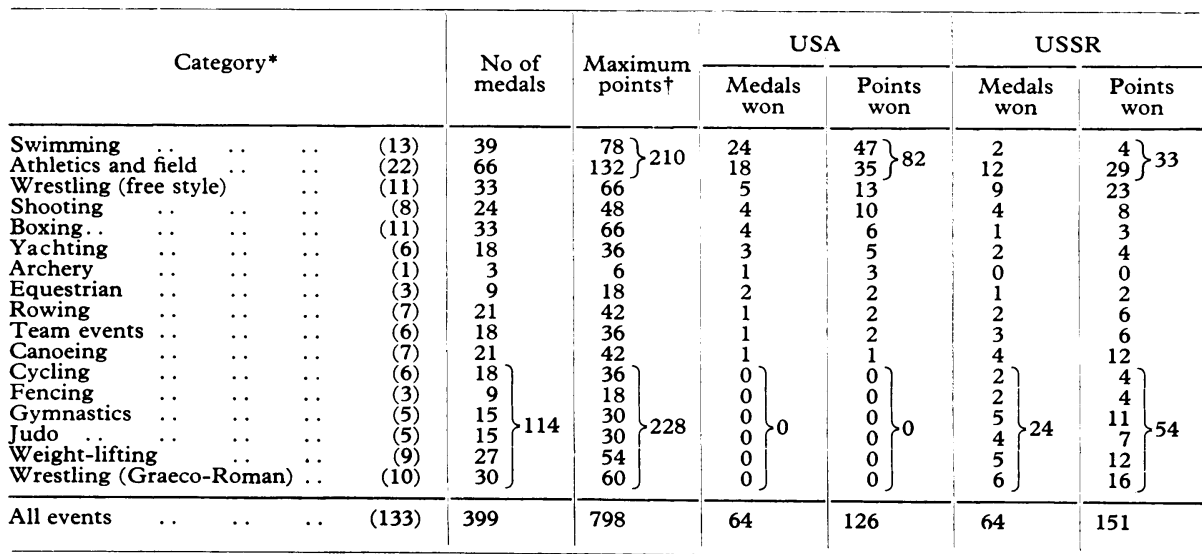

Data collated from three separate volumes published by the organising committee for the Games of the XXth Olympiad, Munich 1972 . Over $80 \%$ of the reported medals are accounted for in the present analysis; theme dal unaccounted for do not introduce any bias in the overall findings.

* Numbers of events are given in parentheses.
$\dagger$ hree points for gold, 2 for silver, 1 for bronze. won by the USA in Munich in 1972. For example $\overrightarrow{\vec{F}}$ the USA dominated the swimming events by winning $61 \%$ of the 39 medals $(60 \%$ of maximum points). Of the total 126 points won by the USA, $82(65 \%)$ were derived from swimming, athletics, and field events. But these events contributed only $26 \%$ of the 798 maximum points. In contrast, the USA did not win any points in cycling, fencing, gymnastics, 3 . judo, weight-lifting, or Graeco-Roman wrestling, which together yield a total of 114 medals or 228 points $(28.6 \%$ of total points). The table shows that the USSR's achievements were $\stackrel{9}{I}$ distributed far more evenly.

Age and height are related to performance; in general, younger age and greater height are $\frac{D}{0}$ advantageous factors. The USA male medallists were both younger and taller than the $N$ Soviet medallists, their mean age $( \pm S D) N$ being $24.5 \pm 5.8$ years compared with $27.0 \pm 0$ 4.6 years for the Russians and their mean height $183.8 \pm 7.5 \mathrm{~cm}$ compared with $177.6 \pm \stackrel{0}{\complement}$ $10 \cdot 2 \mathrm{~cm}$. The mean height of the general male $\mathbb{\infty}$ population of the USA is $174 \cdot 2 \pm 6.9 \mathrm{~cm}$ and in the USSR it is of the same order or lower. The finding that the USA lost her lead to the USSR despite the seemingly advantageous factors arising from younger age and greater $\mathbb{D}$ height needs explanation. Champion swimmers are both young and tall. The overwhelming domination by the USA in the swimming events is reflected in the younger mean age and greater mean height of her champions. Because height and weight are positively correlated, lightweight champions from many of the 46 weight-graded events (wrestling, weight-lifting, etc) are of average or less than average height, ${ }^{12}$ and in 24 of these events the USA failed to win any medals. To regain 
her position America must look for potential champions among her humbler citizens of average and less than average height and strengthen the weaknesses in cycling, fencing, gymnastics, and canoeing events.

T KHOSLA

Department of Medical Statistics,
Welsh National School of Medicine,

Cardiff

' Khosla, T, British Medical fournal, 1968, 4, 111.

Kosla, T, British Fournal of Preventive and Social
Medicine, 1971, 25, 114 .

\section{Priorities in the NHS}

SIR,-Your leading article (12 June, $p$ 1425) reads as an attempted defence of a poor, persecuted minority-the consultants in acute general hospitals. We all live in difficult times. No doubt they will have the sympathy of those wealthier than themselves with more resources at their disposal. What worries me is what you say in their defence and what you don't say.

For instance, you were challenged ( 24 April, p 1013) to justify a figure quoted ("every drop of even $0 \cdot 1^{\circ}{ }_{0} \ldots$..') in a previous leading article (3 April, p 787). Usually such challenges are answered by a reference, an explanation, or an apology. Your technique is a vague quote, from a source not entirely free from bias. In addition you argue about "absolute standards" in medicine. "If a . . new drug or procedure has been proved to make a substantial difference to mortality or morbidity then the doctors working in the specialty will not be content until they use the new treatment on their patients." For the world as a whole the statement is clearly untrue, but even in Britain I have some doubts-although much depends on how you define "proof" and "substantial," and the choice of referee, when there is conflict between specialties. Even so I would argue that there are other factors involved, such as the degree of effectiveness, the cost, the age and general health of the patient, and his or her wishes. You also mention diagnostic aids. For many years it has been known that if, before giving barbiturate anaesthetics, patients were tested the reduction in specific mortality for porphyria might be substantial. My family would profit from such a routine but I have always understood that it was not done because it was not cost-effective-and I rather agree. Your other point concerns "workhouses." I agree that they are depressing places to work in, and to die in, but do new buildings really affect morbidity, mortality, or morale? I observe in Cardiff and remain sceptical.

The omissions in your defence are even odder. You seem curiously unaware of the rising tide of criticism of these consultants over the past 10 years. It is based in genera on their inability to justify the vast increase in their resources by evidence of a comparable increase in "output." In greater detail on could cite the lack of reaction on behalf of these consultants to a considerable mass of observational and experimental evidence about the effectiveness of some treatments, place of treatment, and length of stay in hospital. Possibly the most striking example is the conspiracy of silence with which the cardiologists have welcomed Gordon Mather's comparison of case fatality in coronary care units and at home. ${ }^{1}$ I know from my travels that it is much more discussed abroad than here, where it represents our one big chance to save both lives and money at the same time. It is evidence of this nature without adequate reply which has convinced so many people, medical and lay, that the acute sector could well survive a cut in resources without detriment to outcome.

I would in conclusion like to stress areas of agreement. I would agree that there are possibly too many administrators. It is unfortunately at present impossible to measure their ineffectiveness. Similarly, I am suspicious of the rapid growth of the social services without proper evaluation. Finally, I can't agree more about over-prescribing, but what has the $\mathrm{BMA}$ done to control it?

A L Cochrane

Rhoose,

S Glamorgan

Mather, H G, et al, British Medical fournal, 1 976, 1, 925.

* * Professor Cochrane wants specific examples. We would suggest factor VIII concentrate for haemophilia; total hip replacement for osteoarthritis; the use of fibre endoscopes in the management of upper intestinal haemorrhage; dialysis for end-stage renal failure intermittent positive pressure respiration for infants with respiratory distress syndrome pacemakers for old people with hazardous arrhythmias. In all of these cases financia restraints have forced clinicians to operate some rationing system.-ED $B M \mathcal{F}$.

SIR,-It is natural enough that any section of the NHS (or indeed any other service industry) should protest at being selected for a cut in resources. The pros and cons of choosing obstetrics will be hotly debated for a long time to come. However, your leading article (12 June, $p$ 1425) has taken the opportunity of this debate to lash out at the most underprivileged and underfinanced part of the NHS.

In your view "There is . . . no logic in a decision to spend more money on the mentally handicapped and less on the maternity services, which, if improved still further, might well reduce the amount of mental handicap in the community." In my view, this statement is nonsense. What evidence is there that mental handicap, except in a tiny proportion of cases, is caused by deficient maternity services? Is it true to say that as maternity services have improved over the past 50 years or so the numbers of mentally handicapped people have fallen? There is even a case to argue that a few mentally handicapped people would not have survived their birth if maternity care had been worse. More would have died in the first year of life if the neonatal care offered had been of a lower standard. Surely you would not argue the reverse and say that for these reasons maternity and neonatal standards should be reduced?

The real irony of your argument is in the statement that "the Department seems not to understand that there are some absolute standards in medicine." As far as mental handicap is concerned it seems to be you who fail to grasp this point. Let us face up to the fact that in many mental handicap hospitals, despite the valiant efforts of staff, those absolute standards are not being achieved simply because the hospitals have been starved of resources. Readers who doubt this should take the opportunity of visiting their local mental handicap hospital and discussing these problems with the staff concerned. All too often wild comments about one sector of the NHS are made by another simply because there is a lack of knowledge of the problems involved.

Special Hospitals Research Unit,

JOHN GuNN Institute of Psychiatry,
London SE5

SIR,-In your leading article "Priorities and morale in the NHS" (12 June, p 1425) you say: "If there is no prospect of a hospital providing its staff with the means to give their patients optimum medical care then many of them will look for work in a medical setting that can provide those means. That-not greed for higher pay-is the reason that many dedicated young doctors ... a are looking for jobs overseas." This refers particularly to the suggested $2^{\circ}$, per annum future cut in the cost of maternity services to match the $5 \%$ per annum cut in the birth rate over the past five years.

Where are these doctors to look? Not to Canada, Australia, or the USA, whither go the majority of our emigrants. These are not countries that provide optimum maternity care by British standards as measured by maternal or neonatal mortality, no matter what technical facilities they may offer (see table). To the EEC? Only Denmark and the Netherlands are able to show anything like comparable outcome of pregnancy to that experienced in England and Wales.

\begin{tabular}{|c|c|c|c|}
\hline \multicolumn{2}{|l|}{ Country } & $\begin{array}{c}\text { Maternal } \\
\text { mortality } \\
\text { per } 100000 \\
\text { births }\end{array}$ & $\begin{array}{c}\text { Neonatal } \\
\text { mortality } \\
\text { per } 1000 \text { live } \\
\text { births }\end{array}$ \\
\hline $\begin{array}{ll}\text { Australia } & \ldots \\
\text { Canada } & \ldots \\
\text { USA } & \ldots\end{array}$ & $\begin{array}{l}\ldots \\
\cdots\end{array}$ & $\begin{array}{l}25 \cdot 6 \\
20 \cdot 2 \\
22 \cdot 4\end{array}$ & $\begin{array}{l}13 \cdot 0 \\
13.5 \\
15 \cdot 7\end{array}$ \\
\hline $\begin{array}{l}\text { France } \\
\text { Germany (FDR) } \\
\text { Italy } \\
\text { Irish Republic }\end{array}$ & $\begin{array}{l}\cdots \\
\cdots \\
\cdots\end{array}$ & $\begin{array}{l}28 \cdot 2 \\
51 \cdot 8 \\
54 \cdot 5 \\
31 \cdot 1\end{array}$ & $\begin{array}{l}12 \cdot 6 \\
18 \cdot 4 \\
20 \cdot 4 \\
12 \cdot 8\end{array}$ \\
\hline $\begin{array}{l}\text { Denmark } \\
\text { Netherlands } \\
\text { England and Wale }\end{array}$ & & $\begin{array}{r}8 \cdot 5 \\
13 \cdot 4 \\
18 \cdot 6\end{array}$ & $\begin{array}{r}11 \cdot 0 \\
9 \cdot 5 \\
12 \cdot 3\end{array}$ \\
\hline
\end{tabular}

From World Health Statistics Annual, 1970. Geneva, WHO, 1973

Surely medicine is about curing and caring for the sick to the best of our knowledge with the resources that are available. Politics is about allocating those resources. Science is about the validity of our knowledge. All three are bound to interact with one another, but we must keep the concepts distinct or confusion, and hence lowered morale, will ensue. It is this confusion that has unsettled our profession for so long.

Department of Medical Statistics,

H CAMPBELL

Welsh National School of Medicine

Cardiff

\section{Glucose is dextrose is glucose}

SIR,-A patient who is suspected of having a disease that affects the metabolism of glucose is often subjected to a glucose tolerance test. In the department of chemical pathology 50 $100 \mathrm{~g}$ may be weighed out from a bottle labelled "glucose" and given orally, and the plasma glucose concentration and urinary glucose are measured at intervals. The patient who develops hypoglycaemia or needs intravenous fluid is usually, however, treated with an infusion labelled "dextrose." 